\title{
Original Article \\ Pattern of Blood Transfusion in the Special Care Baby Unit of Benue State University Teaching Hospital in Makurdi North-Central Nigeria
}

\author{
Ochoga M O, Eseigbe E E, ${ }^{1}$ Onoja A M, Michael A, ${ }^{1}$ Samba B $N,{ }^{1}$ Abah R $O,{ }^{1}$ Abdallah $R .{ }^{1}$ \\ ${ }^{\prime}$ Department of Paediatrics, College of Health Sciences, Benue State University/Benue State \\ University Teaching Hospital, Makurdi,Benue State, Nigeria. \\ ${ }^{2}$ Department of Haematology, College of Health Sciences, Benue State University/Benue State \\ University Teaching Hospital, Makurdi, Benue State, Nigeria.
}

OPEN ACCESS

*Correspondence: Ochoga Martha Omoo. Department of Paediatrics, Benue State University Teaching Hospital, Makurdi, Benue State, Nigeria. Email:ochogamartha@gmail.com

Specialty section: This article was submitted to Paediatrics, a section of JRBCS

Received: 7 May 2021 Accepted: 10 June 2021 Published: 30 June 2021

Citation:

Ochoga $M O$, Eseigbe $E E$ Onoja A M, Michael A, Samba B $N$, Abah R $O$, Abdallah R. Pattern of Blood Transfusion in the Special Care Baby Unit of Вепие State University Teaching Hospital in Makurdi, NorthCentral Nigeria. J Res Bas Clin Sci 2(1):9-16 DOI.10.46912/jrbcs. 93

Access Code

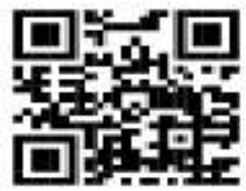

http://jrbc.org

\begin{abstract}
Blood transfusion is a life-saving procedure in which whole blood or parts of blood are introduced into a patient's bloodstream intravenously. The need maybe due to physiological or pathological causes. The objective of this study was to document the pattern and indications for blood transfusion at the Special Care Baby Unit of the Benue State University Teaching Hospital (BSUTH), Makurdi. This study was a retrospective review of 126 neonates who received blood transfusion at the Special care baby unit of BSUTH from 1st January 2015 to 31st December 2019. Data was retrieved from patient's medical records and analyzed using IBM SPSS version 23. A total of 1142 neonates were admitted over the study period and 126 had blood transfusion giving a prevalence of $11.0 \%$. Male/Female ratio of 1.57:1.Mean $( \pm \mathrm{SD})$ Birth weight and gestational age (GA) were $2.23 \pm 0.82 \mathrm{Kg}$ and $35.48 \pm 3.95$ weeks respectively. Exchange blood transfusion was the most frequent 53(42.1\%) type of blood transfusion. The most common indications for blood transfusion were anaemia of prematurity, sepsis and severe neonatal jaundice. A hundred and twelve $(88.9 \%)$ who received transfusion were discharged while $4(3.2 \%)$ died. The rate of blood transfusion was low, while severe neonatal jaundice and anaemia were the main indications for blood transfusion in this study. Exchange blood transfusion was the main type of transfusion.
\end{abstract}

Keyword: Blood transfusion, Indication, Newborn, SCBU.

\section{INTRODUCTION}

$\mathrm{B}$ lood transfusion is a lifesaving procedure in which whole blood or parts of blood are introduced into a patient's bloodstream intravenously. ${ }^{1}$ It is an important form of treatment in the paediatric age group where illnesses are associated with destruction, loss and deterioration in blood and its constituents. In wealthy countries, the majority of transfusions are carried out electively and mostly 
for patients over 60 years of age, however in low income countries, up to $54 \%$ of transfusions are for children under the age of 5 - years. ${ }^{2}$ The need for blood transfusion in neonates may occur due to physiological or pathological causes. ${ }^{3}$ Globally a cohort study undertaken in a neonatal intensive care unit reported a transfusion rate of $13.4 \%{ }^{4}$ In Nigeria Pam S et al ${ }^{5}$ from Jos north-central Nigeria reported a prevalence of $16.7 \%$ as compared to $27.9 \%$ by Ogunlesi TA from South west Nigeria. ${ }^{6}$

There is an enormous need for blood transfusion in the newborn particularly due to the reduced marrow activity in the new born period. ${ }^{7}$ Moreover preterm infants require transfusions for several reasons such as lower hemoglobin levels at birth, low levels of erythropoietin in addition to a hyporegenerative bone marrow with attendant anaemia of prematurity. Repeated blood sampling of infants requiring frequent monitoring is another common cause of anemia among hospitalized infants. ${ }^{9}$

The major causes of neonatal morbidity and mortality that require hospital admission such as prematurity, neonatal infections and neonatal jaundice require blood transfusion in their management with either top up transfusions or in form of exchange blood transfusion leading to the high rates of transfusions among newborns. ${ }^{10}$ Despite several efforts there still remains some controversy about the threshold for transfusion in newborns and the lack of a well developed transfusion service. The rate of blood transfusion is still very high among neonates in Nigeria with the major indications being severe anaemia, anaemia of prematurity, neonatal jaundice, neonatal sepsis, bleeding disorders. ${ }^{3}$ Since blood transfusion is associated with potential risks and adverse effects, it is therefore pertinent to ensure that it is given only when it is indicated. Despite significant improvement brought to blood testing and handling, there remain both infectious and non-infectious risks associated with allogenic blood transfusions."

While there are reports of the pattern of blood transfusion in other centres, there is a paucity of local data on the patterns of blood transfusion in our locality.
Hence this study was aimed to document the pattern and indications for blood transfusions at the Special Care Baby Unit of the Benue State University Teaching Hospital (BSUTH) a tertiary institution in Makurdi, which serves several communities and neighbouring States in North Central and South Eastern Nigeria, and with a view to set up a protocol for neonatal transfusion.

\section{MATERIALS AND METHODS}

This retrospective study was conducted in the Special Care Baby Unit (SCBU) of Benue State University Teaching hospital over a 5 -year period from $1^{\text {st }}$ January 2015 to $31^{\text {st }}$ December 2019.The Benue State University Teaching Hospital is a tertiary center located in Makurdi which is the state capital. The hospital provides specialist care to the inhabitants of the state capital and the state at large. It has a department of Paediatrics that is manned by specialist doctors as well as trained nurses who attend to newborns delivered in the facility as well as those referred from other facilities. The special care baby unit caters to the needs of newborns delivered in the facility who get admitted into the inborn section as well as the needs of newborns referred from other facilities. The Unit is supervised by a Consultant neonatologist and has resident doctors providing services while undergoing clinical rotation in the Unit. All newborns admitted into the neonatal unit during the study period that had blood transfusion were recruited.

The hospital records of all the neonates who received a blood transfusion were analyzed .The data obtained from the patient's medical records included: Gestation at birth, birth weight, age at admission, sex, presenting complaints, indication for transfusion, blood products used, number of transfusions, transfusion reactions, duration of hospital stay and outcome.

The guideline for transfusion in our SCBU is as follows:

1. All neonates within the first week of life with a packed cell volume $(\mathrm{PCV})<35 \%$ are transfused with 
sedimented cells at $15 \mathrm{mls} / \mathrm{Kg}$ in aliquots

2. Neonates outside the first week of life presenting with PCV $<30 \%$ are transfused with sedimented cells at $15 \mathrm{mls} / \mathrm{Kg}$ in aliquots

3. Neonates presenting with severe neonatal jaundice complicated by severe anaemia of PCV $<30 \%$, or presenting with severe sepsis or disseminated intravascular coagulopathy undergo a double volume EBT.

Ethical approval was obtained from the Benue State University Teaching Hospital Health Research Ethics committee.

Data was analyzed using IBM SPSS Statistics for Windows, version 23, Armonk. NY: IBM Corp and presented as tables and figures.

\section{RESULTS}

A total of 1142 neonates were admitted over the study period. Of these $126(11.0 \%)$ were transfused with one blood product or the other. Table 1 shows the sociodemographic characteristics of mothers. The mean age of mothers was $27.33 \pm 4.55$ years. The majority $(40.5 \%)$ of mothers were aged 23-27 years. The mean gestational age was $35.48 \pm 3.95$ weeks. Over half $(52.4 \%)$ of mothers delivered at a gestational age between $36-40$ weeks. The majority $(81.7 \%)$ of the mothers had a singleton delivery. A greater percentage (79.4\%) of the mothers had vaginal delivery.

As shown in table 2, the median age of the neonates was 3.0 days at admission. The majority of the neonates were aged 1-5 days. Nearly two-third (61.1\%) of the babies were males, while $38.9 \%$ were females with a male to female ratio of $1.57: 1$. The mean weight of the neonates was $2.23 \pm 0.82 \mathrm{~kg}$. Above half of the babies $(55.6 \%)$ were low birth weights. The majority of the neonates ( $46.9 \%$ ) had blood group $\mathrm{O}+$, followed by (30.6\%) blood group B.

Table 3 showed indications for RBC transfusion. About half $(42.1 \%)$ of the neonates had Severe NNJ as an indication for RBC transfusion, followed by $25.4 \%$ of
Table 1: Socio-demographic characteristics of mothers $(\mathrm{N}=126)$

\begin{tabular}{|c|c|c|}
\hline $\begin{array}{l}\text { Variables } \\
\text { Maternal age (in }\end{array}$ & Frequency & Percent \\
\hline $18-22$ & 17 & 13.5 \\
\hline $23-27$ & 51 & 40.5 \\
\hline $28-32$ & 44 & 34.9 \\
\hline $33-37$ & 12 & 9.5 \\
\hline $38-42$ & 2 & 1.6 \\
\hline \multicolumn{3}{|c|}{ Mean $\pm S D=27.33 \pm 4.55$} \\
\hline \multicolumn{3}{|c|}{ Gestational Age (in weeks) } \\
\hline$<28$ & 3 & 2.4 \\
\hline $28-37$ & 75 & 59.5 \\
\hline$>37$ & 48 & 38.1 \\
\hline \multicolumn{3}{|c|}{ Mean \pm SD $=35.48 \pm 3.95$} \\
\hline \multicolumn{3}{|l|}{ Birth type } \\
\hline Single & 103 & 81.7 \\
\hline Multiple & 23 & 18.3 \\
\hline \multicolumn{3}{|l|}{ Mode of delivery } \\
\hline Vaginal & 100 & 79.4 \\
\hline Caesarean section & 26 & 20.6 \\
\hline
\end{tabular}

Table 2: Baby's Characteristics ( $N=126)$

\begin{tabular}{lrr}
\hline $\begin{array}{l}\text { Variables } \\
\text { Baby's age (in days) }\end{array}$ & Frequency & Percent \\
\hline $1-5$ & 91 & 72.2 \\
$6-10$ & 17 & 13.5 \\
$11-15$ & 6 & 4.8 \\
$>15$ & 12 & 9.5 \\
Median=3.00 & & \\
Sex & & \\
Male & 77 & 61.1 \\
Female & 49 & 38.9 \\
Weight (in kg) & & \\
Extreme low birth weight & $\mathbf{7}$ & 5.6 \\
Very low birth weight & 21 & 16.7 \\
Low birth weight & 42 & 33.3 \\
Normal birth weight & 56 & 44.4 \\
Mean \pm SD=2.23 $\pm \mathbf{0 . 8 2}$ & & \\
Blood group(N=98) & & \\
O+ & & \\
B & 46 & 46.9 \\
A & 30 & 30.6 \\
AB & 20 & 20.4 \\
\hline
\end{tabular}


the babies who had anaemia of prematurity.

The majority of the neonates (39.7\%) had 1 EBT. Out of 60 neonates, $35(58.3 \%)$ had one top-up transfusion. Exchange blood transfusion was the commonest practice (Table 4).

As shown in Table 5,majority of the neonates (88.9\%) were discharged, while 7.9\% discharged against medical advice (DAMA) and 4\% died. About half of the neonates (42.9\%) had 1-10 day's duration of hospital stay.

Table 6 showed the association of age, gestational age, birth weight and duration of hospital stay. There was no statistically significant association between all the variables and the outcome variables.

Table 3: Indications for $\mathrm{RBC}$ transfusion ( $\mathrm{N}=126)$

\begin{tabular}{lrr}
\hline $\begin{array}{l}\text { Variables } \\
\text { Indications }\end{array}$ & Frequency & Percent \\
\hline Anemia from prematurity & 32 & 25.4 \\
Overwhelming sepsis & 23 & 18.3 \\
Severe NNJ & 53 & 42.1 \\
Anemia from prematurity and severe NNJ & 6 & 4.8 \\
Overwhelming sepsis and severe NNJ & 2 & 1.6 \\
Severe NNJ and bleeding disorder & 1 & 0.8 \\
Others & 9 & 7.1 \\
\hline
\end{tabular}

Table 4: Distribution of transfusion among subjects $(\mathrm{N}=126)$

\begin{tabular}{lrr}
\hline $\begin{array}{l}\text { Variables } \\
\text { Type of transfusion } \\
\text { EBT (N=66) }\end{array}$ & Frequency & Percent \\
\hline 1 & & \\
2 & 50 & 39.7 \\
3 & 15 & 11.9 \\
Top up transfusion (N=60) & 1 & 0.8 \\
1 & & \\
2 & 35 & 58.3 \\
3 & 15 & 25.0 \\
4 & 9 & 15.0 \\
Type of blood transfusion & 1 & 1.7 \\
Sedimented RBC & & \\
Whole blood & 47 & 37.3 \\
Exchange Blood transfusion & 15 & 11.9 \\
Sedimented RBC and Exchange blood transfusion & 53 & 42.1 \\
& 11 & 8.7 \\
\hline
\end{tabular}


Table 5: Distribution of treatment outcome

\begin{tabular}{lrr}
\hline $\begin{array}{l}\text { Variables } \\
\text { Treatment outcome }\end{array}$ & Frequency & Percent \\
\hline Discharged & 112 & 88.9 \\
Died & 4 & 3.2 \\
DAMA & 10 & 7.9 \\
Duration of hospital stay (in days) & & \\
$1-10$ & 54 & 42.9 \\
$11-20$ & 28 & 22.2 \\
$21-30$ & 19 & 15.1 \\
$31-40$ & 11 & 8.7 \\
$>40$ & 14 & 11.1 \\
Mean \pm SD=18.51 $\pm \mathbf{1 4 . 2 7}$ & & \\
\hline
\end{tabular}

Table 6: Distribution of gestational age, EBT and indication by Sex

\begin{tabular}{lrrr}
\hline Variables & \multicolumn{2}{c}{ Sex } \\
& $\begin{array}{r}\text { Males } \\
\mathbf{N = 7 7} \\
\mathbf{n}(\boldsymbol{\%})\end{array}$ & $\begin{array}{c}\text { Females } \\
\mathbf{N = 4 9} \\
\mathbf{n}(\boldsymbol{\%})\end{array}$ & p-value \\
Gestational age & & & 0.668 \\
Pre-term<37 weeks & $41(59.4)$ & $28(40.6)$ & \\
Term $\geq 37$ weeks & $36(63.2)$ & $21(36.8)$ & \\
EBT & & & 0.205 \\
1 & $35(70.0)$ & $15(30.0)$ & \\
2 & $8(53.3)$ & $7(46.7)$ & \\
3 & $0(0.0)$ & $1(100.0)$ & \multirow{2}{*}{} \\
Indication & & \\
Anemia from prematurity & $19(59.4)$ & $13(40.6)$ & \\
Overwhelming sepsis & $13(56.5)$ & $10(43.5)$ & \\
Severe NNJ & $36(67.9)$ & $17(32.1)$ & \\
Anemia from prematurity and severe NNJ & $6(66.7)$ & $3(33.3)$ & \\
Overwhelming sepsis and severe NNJ & $2(33.3)$ & $4(66.7)$ & \\
Severe NNJ and bleeding disorder & $1(50.0)$ & $1(50.0)$ & \\
Others & $0(0.0)$ & $1(100.0)$ & \\
\hline
\end{tabular}


Table 7: Association of outcome and age, gestational age, birth weight, and duration of hospital stay

\begin{tabular}{|c|c|c|c|c|}
\hline \multirow{2}{*}{ Variables } & \multicolumn{4}{|c|}{ Outcome } \\
\hline & $\begin{array}{c}\text { Discharge } \\
\mathbf{N}=112 \\
\mathbf{n}(\%)\end{array}$ & $\begin{array}{l}\text { Died } \\
N=4 \\
n(\%)\end{array}$ & $\begin{array}{c}\text { DAMA } \\
\text { N=10 } \\
\text { n(\%) }\end{array}$ & p-value \\
\hline Baby's age (in days) & & & & 0.389 \\
\hline $1-5$ & $81(89.0)$ & $4(4.4)$ & $6(6.6)$ & \\
\hline $6-10$ & $16(94.1)$ & $0(0.0)$ & 1(5.9) & \\
\hline $11-15$ & $4(66.7)$ & $0(0.0)$ & $2(33.3)$ & \\
\hline$>15$ & $11(91.7)$ & $0(0.0)$ & $1(8.3)$ & \\
\hline Gestational Age (in weeks) & & & & 2.51 \\
\hline$<28$ & $3(100.0)$ & $0(0.0)$ & $0(0.0)$ & \\
\hline $28-37$ & $64(85.3)$ & $3(4.0)$ & $8(10.7)$ & \\
\hline$>37$ & $45(93.8)$ & $1(2.1)$ & $2(4.2)$ & \\
\hline Weight (in kg) & & & & 0.316 \\
\hline Low birth weight & $60(85.7)$ & $2(2.9)$ & $8(11.4)$ & \\
\hline Normal birth weight & $52(92.9)$ & $2(3.6)$ & $2(3.6)$ & \\
\hline Duration of hospital stay (in days) & & & & 0.150 \\
\hline $1-10$ & $50(92.6)$ & $1(1.9)$ & $3(5.6)$ & \\
\hline $11-20$ & $23(82.1)$ & $1(3.6)$ & $4(14.3)$ & \\
\hline $21-30$ & $17(89.5)$ & $2(10.5)$ & $0(0.0)$ & \\
\hline $31-40$ & $11(100.0)$ & $0(0.0)$ & $0(0.0)$ & \\
\hline$>40$ & $11(78.6)$ & $0(0.0)$ & $3(21.4)$ & \\
\hline
\end{tabular}

\section{DISCUSSION}

This study showed that most transfusions in our SCBU involved the use of sedimented red blood cells and whole blood as we lack facilities to administer other blood products. The commonest indication for transfusion was severe neonatal jaundice. This is similar to the experience of some other centres. ${ }^{5,6,12,13}$ The prevalence of blood transfusion was $11.0 \%$ in the present study and similar to $11.7 \%$ reported by JoelMedewase VI et al in Southwest Nigeria. ${ }^{12}$ However a higher prevalence of blood transfusion was reported by Pam et al from Jos North central Nigeria 16.5\%, Ayede et al $27.9 \%{ }^{13}$ and Ogunlesi et al $30.8 \%{ }^{6}$ both from South Western Nigeria. The reason for the high prevalence in the other study sites could be because they have a comparatively larger population of subjects (e.g preterms) who often require transfusion.
However Jalo et al ${ }^{14}$ in North Eastern Nigeria reported a prevalence of $3.5 \%$, which is lower than the finding in our centre. Their finding could be attributable to a lower proportion of neonates susceptible to transfusion in their study. Our study has demonstrated that Preterms still constitute a significant proportion of the transfused neonates, therefore there is need to promote programmes and policies that prevent prematurity.

From the present study, males were more frequently transfused with blood when compared with the females. Similar patterns were reported from other centres within Nigeria. ${ }^{6,12,15 .}$ However there is no readily available explanation for this male preponderance. In the present study low birth weight $(55.6 \%)$ and preterm $(42.9 \%)$ neonates were frequently transfused and this is similar to patterns reported by earlier 
researchers. ${ }^{5,6,13,16,17}$ Moreover preterm infants require transfusions for several reasons such as lower haemoglobin levels at birth, low levels of erythropoietin in addition to a hyporegenerative bone marrow with attendant anaemia of prematurity. Repeated blood sampling of infants requiring frequent monitoring is another common cause of anaemia among hospitalized infants. ${ }^{9}$

The indications for transfusion in the present study were anaemia of prematurity, sepsis and severe neonatal jaundice (NNJ) which are reflections of the national neonatal burden. ${ }^{10,18}$ Jaundice and anaemia were the commonest indication for blood transfusion similar to that reported by Joel-Medewase VI et al ${ }^{12}$ ,Pam et $a l^{5}$,Ogunlesi et $a l^{6}$ and Jalo I et $a l^{14}$ Aggressive prophlaxis of severe hyperbilirubinaemia using effective methods like phototherapy should reduce the bulk of exchange blood transfusions(EBTs). ${ }^{10,19}$ This is to say that NNJ contributes significantly to the requirements of blood transfusion in the neonatal period. Some of the babies who had EBT in the present study had anaemia requiring a top up transfusion. This maybe as a result of ongoing hemolysis from the primary cause of jaundice such as blood group incompatibilities. Other causes such as bacterial infection resulting from umbilical cannulation and poor mixing of blood used for the procedure may cause sedimentation of cells leading to anaemia. Apart from adequate mixing of blood during EBT, there is little that can be done to stop post-EBT anaemia, especially when there is on going hemolysis. More than half of the babies in our study had several transfusions, unlike $29 \%$ reported from Jos, Nigeria. ${ }^{5}$ The outcome in the present study was good as $88.9 \%$ of the neonates were discharged.

\section{CONCLUSION}

The transfusion rate in our SCBU was low when compared to most of the studies. The major indications for transfusion were anaemia and severe hyperbilirubinaemia. EBT was the main type of transfusion among the neonates in this study. There is need to promote measures that prevent indications for EBT and employ other less problematic modalities for treatment of severe hyperbilirubinemia e.g intensive phototherapy and the use of tin protoporphrin.We Suggest preventive measures against development of conditions that lead to need for transfusion. These includes adequate $\mathrm{ANC}$, prevention of neonatal sepsis, developing capacities of SCBU staff to be able to provide non transfusion therapy where indicated, and implementation of National Newborn Care Policies

\section{Limitation}

The retrospective nature of this study limited the exploration of other factors (e. g parental/socio cultural perception about blood transfusion) associated with neonatal blood transfusion. The present study has identified risk factors for neonatal blood transfusion in our practice and the need to obviate them. The study underscores the need to implement measures against the incidence of prematurity and neonatal jaundice in our environment of practice.

\section{Conflict of Interest: None declared}

\section{REFERENCES}

1. Obeta MU, Obeta KO, Lugus MD. Current Trend in Blood Transfusion Science, Where are we? Haematol Int J 2020;4(2):000159

2. World Health Organization (WHO) Blood safety and availability. WHO global Database on blood safety from 108 countries for the year 2018. www.who.int/news-room/fact-sheets/detail/bloodsafety-and availability accessed june 10,2020.

3. Kufsa IU, Mamman AI, Ibrahim IN, Benjamin A, Yahaya G, Musa $\mathrm{S}$ et al. Indications and patterns of blood transfusion in neonatal intensive care unit of a tertiary hospital in North West Nigeria. Ann Trop Pathol 2019;10:132-5. doi:10.4103/atp.atp_69_18

4. Villeneuve A, Lapointe A, Lachance C, et al.: Epidemiology and determinants of transfusions of 
red blood cells, plasma and platelets in a neonatal intensive care unit (NICU): a single center cohort study. Paediatr Child Health 2014; 19:e58

5. Pam S, Bode-Thomas F, Joseph DE, Akor F, Ejeliogu E. Which babies get blood in Jos, Nigeria?. Pediatr Hematol Oncol. 2004;21(7):669676. https://dx.doi:10.1080/08880010490501097

6. Ogunlesi TA, Ogunfowora OB. Pattern and determinants of blood transfusion in a Nigerian neonatal unit. Niger J Clin Pract.2011;14:354-8 doi:10.4103/1119-3077.86783

7. Monagle P, Andrew M. Developmental haemostasis; Relevance to newborns and infants. In: Nathan DG, Orkin SH, Ginsburg D, eds. Haematology of infancy and childhood. Philadelphia: WB Saunders, 2003: $121-168$

8. Blanchette VS, Zipursky A. Assessment of anemia in newborn infants. Clin Perinatol. 1984;11(2):489510

9. Maheshwari A, Carlo WA. Blood disorders; Anemia in the Newborn Infant. In: Kleigman RM, Stanton BF, St Geme JW, Schor NF (eds). Nelson Textbook of Pediatrics, 20th ed. Philadelphia, WB Saunders Company 2020,880-883.e1

10. Owa JA, Ogunlesi TA. Why are we still doing so many exchange blood transfusion for neonatal jaundice in Nigeria. World J Pediatr. 2009;5(1):51-55

11. Chirico G. Red blood cell transfusion in preterm neonates: current perspectives. International Journal of Clinical Transfusion Medicine 2014;2:21-28. doi:10.2147/IJCTM.S40026

12. Joel-Medewase VI, Olufemi-Aworinde KJ, Alabi AO, Agelebe E, Adebami OJ. Pattern and indications for Neonatal Blood Transfusion in Ogbomoso, southwestern Nigeria. Int J Health Sci Res. 2019;9(10):111-118

13. Ayede AI, Akingbola TS. Pattern, Indications and Review of complications of neonatal blood transfusion in Ibadan, Southwest Nigeria. Ann Ib Postgrad Med.2011;9(1):30-36.

14. Jalo I, Isaac EW, Raymond MP, Amina M,
Adeniji RY. Rate, Indications and Outcome of Blood Transfusion in Neonates at Federal Teaching Hospital, Gombe, Nigeria.West Afr J Med. 2021 Feb;38(2):152-157.PMID:33641150.

15. kusfa IU, Mamman AI,Ibrahim IN,Benjamin A,Yahaya G, Musa S, et al. Indications and patterns of blood transfusion in neonatal intensive care unit of a tertiary hospital in North west Nigeria. Ann Trop Pathol 2019:10:132-5.

16. Blanchette VS, Zipursky A. Assessment of anaemia in newborn infants. Clin Perinatol.1984;11(2):489-510.

17. Stockman JA, 3rd. Anemia of prematurity .Current concepts in the issue of when to transfuse. Pediatr Clin North Am.1986;33(1):11128 .

18. Saving newborn lives in Nigeria: Newborn health in the context of the integrated maternal, newborn and child health strategy, revised. edition $2011 \mathrm{p}$ 1-120.

19. Amadi HO, Abdullahi RA, Mokuolu OA, Ezeanosike OB, Adesina CT, Mohammed IL, et al. Comparative outcome of overhead and total body phototherapy for treatment of severe neonatal jaundice in Nigeria. Paediatrics and International Child health. DOI 10.1080/20469047.2019.16106071 